\title{
Effect of Degree of Cl0- Hypochlorite on the Wet Synthesis of Ferrate (VI)
}

\author{
Abdellatif El Maghraoui, Abdelaziz Zerouale, Mustapha Ijjaali \\ Laboratory of Chemistry of Condensed Mater (LCMC), Faculty of Sciences and Technology, Sidi Mohammed \\ Ben Abdellah University, Fez, Morocco \\ Email: elmaghraabdellatif@yahoo.fr
}

Received 13 December 2014; accepted 19 April 2015; published 22 April 2015

Copyright (C) 2015 by authors and Scientific Research Publishing Inc.

This work is licensed under the Creative Commons Attribution International License (CC BY). http://creativecommons.org/licenses/by/4.0/

(c) (i) Open Access

\section{Abstract}

This work is a result of previously done studies on the synthesis of $\mathrm{A}_{2} \mathrm{Fe}^{\mathrm{VI}} \mathrm{O}_{4}$ wet ferrate (VI) formula, using chlorine as an oxidant. The major problem of these ferrates is related to their stability over time. This brings us to identify and optimize the critical parameters influencing the preparation of the $\mathrm{Na}_{2} \mathrm{FeO}_{4}$ at room stable phase with acceptable performance. The use of water bleach (hypochlorite $\mathrm{ClO}^{-}$) at a chlorometric degree of $5^{\circ} \mathrm{F}$ in the synthesis of the $\mathrm{Na}_{2} \mathrm{FeO}_{4}$ ambient stable phase promotes the oxidation of iron (II) iron to (VI) in a concentrated $\mathrm{NaOH}$ alkaline medium. The synthesis reaction is in the presence of $\mathrm{FeSO}_{4} \mathbf{7 H}_{2} \mathrm{O}$ hydrated iron sulfate at a temperature of about $55^{\circ} \mathrm{C}$ in order to simplify the synthesis process, to enhance the production of the Fe (VI) and to meet the growing demand of ferrates (VI) for their interest in the treatment of water. Monitoring the degradation of synthesized $\mathrm{Na}_{2} \mathrm{FeO}_{4}$ shows its stability up to 12 months, which facilitates storage and transportation. The phases obtained were characterized by IR spectroscopy, and RX by UV spectrophotometer, measuring the optical density at $507 \mathrm{~nm}$.

\section{Keywords}

Ferrates, Bactericides, Antioxidant, Flocculant, Coagulant, Wet, Water Treatment

\section{Introduction}

The ferrate (VI) is a supercharged iron compound in which the iron is in the oxidation state +6 . It is known under the name of iron (VI). The ferrate is extremely powerful, can provide multiple treatments from a single application, does not create disinfection by-products, is environmentally friendly, and solves the difficult treatments which represents the challenges of other oxidants can't touch. The Ferrate treatment option is often the least expensive and most effective. 
The synthesis of ferrate (VI) has been studied by many authors [1]-[11] to be simpler and more suitable methods with a higher yield and stable phases. Despite improvements, the results remain limited.

Ockerman et al. [12] and Scheryer et al. [13] show that the precipitation washing and drying protocols are required to achieve a stable and solid outcome.

Publications and patents for $\mathrm{K}_{2} \mathrm{FeO}_{4}$ synthesis modes recommend the use of a ferric salt [14] [15].

In 1950, Hrostowski and Scott [16] proposed a method to prepare ferrate with a purity of $97 \%$ of ferric chloride by oxidation with sodium hypochlorite in a concentrated sodium hydroxide solution at temperatures ranging between $50^{\circ} \mathrm{C}$ and $55^{\circ} \mathrm{C}$. Now, for the environment in which operate Hrostowski et al. [16] is highly $\mathrm{NaOH}$ concentrated. $\mathrm{Na}_{2} \mathrm{FeO}_{4}$ is assumed very soluble, whereas $\mathrm{NaCl}$ has precipitated in the solution [17], which then makes a separation by filtration possible.

El Maghraoui et al. [18] achieved the synthesis of ambient stable $\mathrm{Na}_{2} \mathrm{FeO}_{4}$ by the oxidation of iron (II) to iron (VI) by electrochemical means.

The wet method is considered the most practical but remains very expensive.

The aim of this work is to synthesize compounds based on stable Iron (VI), particularly $\mathrm{Na}_{2} \mathrm{FeO}_{4}$, at room temperature, to determine the effect of the degree bleach on the synthesis and monitoring of the degradation of Iron (VI) over time.

\section{Material and Method}

First, the hydrated iron sulfate $\mathrm{FeSO}_{4}, 7 \mathrm{H}_{2} \mathrm{O}$ and $\mathrm{ClO}^{-}$bleach $\left(50^{\circ} \mathrm{F}\right)$ are mixed in a $\mathrm{NaOH}$ alkaline medium. The mixture is stirred for one hour at a temperature of $55^{\circ} \mathrm{C}$ until the mixture becomes red purple characterizing the presence of iron (VI).

Recovering $\mathrm{Na}_{2} \mathrm{FeO}_{4}$ is performed by vacuum filtration in order to dry the product at a temperature of $120^{\circ} \mathrm{C}$ for 12 hours. Then, the product is dried in a desiccator for at least one hour before grinding to prevent moisture problem [12].

The obtained final product is analyzed and stored at room temperature in order to monitor its degradation over time.

The synthesis reaction is as follows:

$$
\mathrm{FeSO}_{4}, 7 \mathrm{H}_{2} \mathrm{O}+4 \mathrm{OH}^{-}+2 \mathrm{CLO}^{-} \rightarrow \mathrm{FeSO}_{4}^{2-}+\mathrm{SO}_{4}^{2-}+2 \mathrm{Cl}^{-}+9 \mathrm{H}_{2} \mathrm{O}
$$

\section{Results}

The results obtained are shown in Figure 1 and Figure 2. These show that the yield of the oxidation of iron (II) to iron (VI) varies, depending on the degree of $\mathrm{ClO}^{-}$bleach and the drying time.

According to these results (Figure 1 and Figure 2), we noticed that the increase in the chlorometric degree of $\mathrm{ClO}^{-}$bleach water led to higher yields of the reactions but with a maximum at $50^{\circ} \mathrm{F}$, this shows the significant

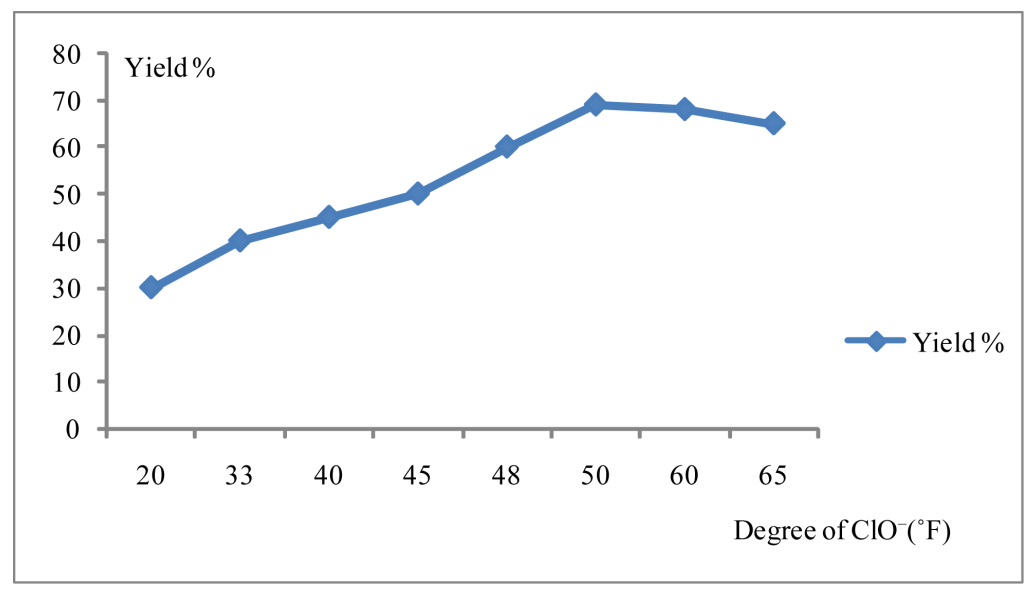

Figure 1. iron oxidation yield (II) to iron (VI) according to the degree of $\mathrm{ClO}^{-}$ bleach to a drying time of 12 hours and at a temperature of $120^{\circ} \mathrm{C}$. 
effect of the degree of bleach water on the oxidation of iron (II) to iron (VI). The optimal drying time to achieve a yield of $70 \%$ iron (VI) is stable at ambient for 12 hours.

\section{Characterization}

\subsection{Infrared Spectroscopy}

The appearance of an infrared spectrum is related to the symmetry of the molecule or group studied. It is expected to $\mathrm{FeO}_{4}^{2-}$ tetrahedral structure to find:

Fundamental characteristic bands of symmetry $\tau \mathrm{d}$ : either $v_{3}, v_{4}$ bands and from the two degenerate modes of vibration: the symmetrical angular elongations and deformations within the tetrahedron resulting in inactive modes in infrared absorption, bands and the $v_{1}, v_{2}$ must be absent from the spectra [19]. Similarity between infrared spectrum isomorphic series [20].

The presence of the $v_{1}$ band and a triplet for $v_{3}$ (elongation of the tetrahedron) led Griffith (1966) to consider a lower symmetry $\tau$ d, very close to $\tau_{S}$ for $\mathrm{FeO}_{4}^{2-}$ anion [21]. IR spectroscopy is a quantitative method for the determination of Iron (VI) compounds in ferrates. The shape of the spectra is due to the symmetry of the molecule or $\mathrm{FeO}_{4}^{2-}$ groups (tetrahedral structure). The IR spectrum of the obtained $\mathrm{Na}_{2} \mathrm{FeO}_{4}$ (user 820 and $770 \mathrm{~cm}^{-1}$ ) (Figure 3) showed an identical appearance to that obtained in the high frequency domain [22].

Comparing the outgoing strip $820 \mathrm{~cm}^{-1}$ and $770 \mathrm{~cm}^{-1}$ IR spectrum (Figure 3) of the phase with that of $\mathrm{Na}_{2} \mathrm{FeO}_{4}$, Weichun et al. [5] observed a similarity of these spectra with light bands of travel $\mathrm{Na}_{2} \mathrm{FeO}_{4}$ which may be due to the conditions of preparation and crystallization.

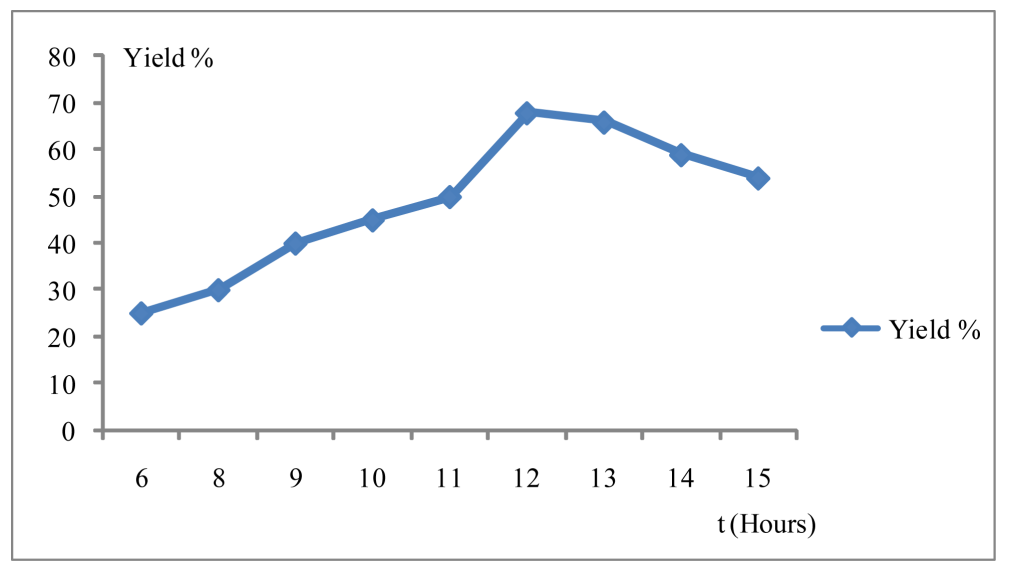

Figure 2. iron oxidation yield (II) to iron (VI) according to the product of the drying time at a temperature of $120^{\circ} \mathrm{C}$ and the degree of $\mathrm{ClO}^{-}$bleach $50^{\circ} \mathrm{F}$.

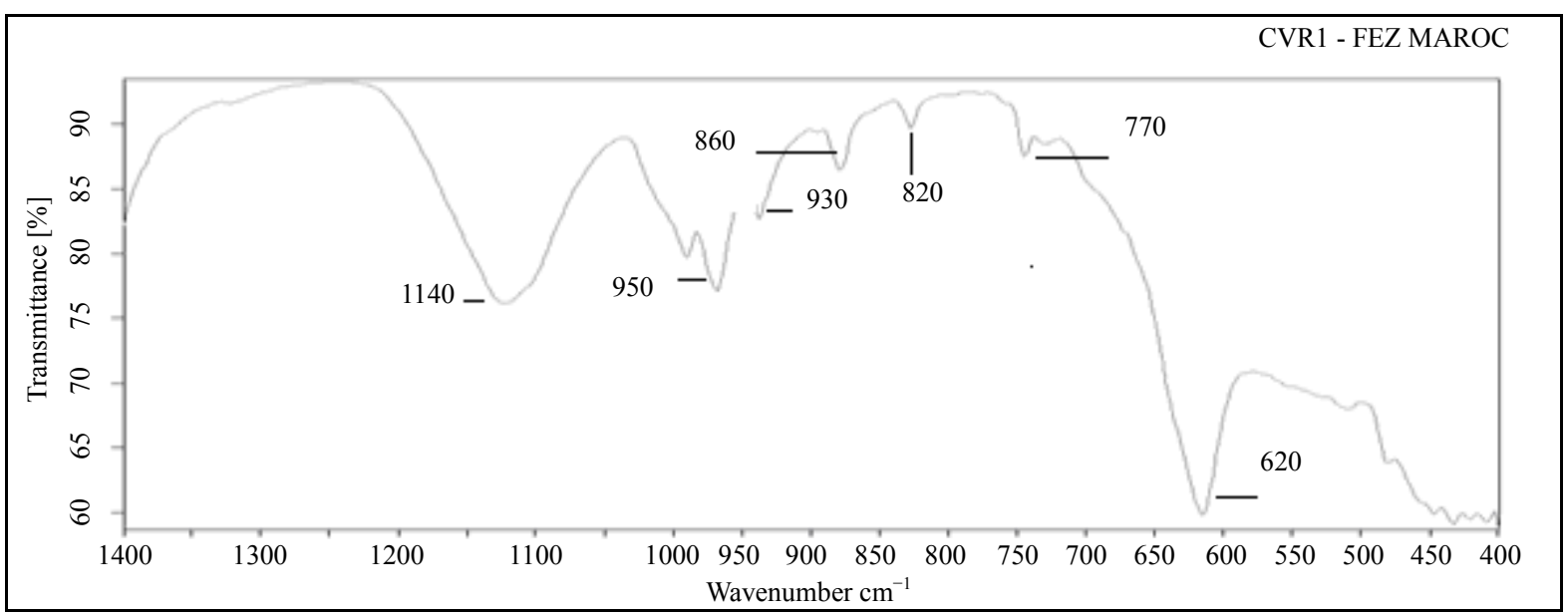

Figure 3. Spectrum infra-red prepared $\mathrm{Na}_{2} \mathrm{FeO}_{4}$. 
The bands $1140 \mathrm{~cm}^{-1}$ and $620 \mathrm{~cm}^{-1}$ are characteristic of $\mathrm{SO}_{4}^{2-}$ group, while those at $950 \mathrm{~cm}^{-1}, 930 \mathrm{~cm}^{-1}$ and $860 \mathrm{~cm}^{-1}$ can be assigned to an intermediate compound between $\mathrm{Na}_{2} \mathrm{SO}_{4}$ and $\mathrm{Na}_{2} \mathrm{FeO}_{4}$ form of a solid solution of the formula $\mathrm{Na}_{2} \mathrm{Fe}_{\mathrm{x}} \mathrm{S}_{1-\mathrm{x}} \mathrm{O}_{4}$ : sulfate-ferrate [23].

\subsection{X-Ray Diffraction}

The XRD spectrum obtained for $\mathrm{Na}_{2} \mathrm{FeO}_{4}$ powdered compound (Figure 4) to verify the crystal structure of this phase [24] [25] and demonstrate the existence of an isomorphism with $\mathrm{K}_{2} \mathrm{FeO}_{4}$ and $\mathrm{BaFeO}_{4}$ found by Licht et al. [3]. Dropoff window Diffraction RX is one of the means used to verify the presence of ferrate (VI).

$\mathrm{Na}_{2} \mathrm{FeO}_{4}$ the spectrum obtained shows similarity with that of isomorphous compounds including $\mathrm{K}_{2} \mathrm{FeO}_{4}[8]$.

There is a duplication of lines corresponding to the planes (102), (202), (013), (200), (002), (004,) (105), (226), (114), (205), (412), (006), (026), (008), (301) [3] [5] [6] [8] [26]-[29].

We note the existence of the lines in the X-ray diffractogram of $\mathrm{Na}_{2} \mathrm{FeO}_{4}$ not observed in that of $\mathrm{K}_{2} \mathrm{FeO}_{4}$. These lines can be assigned to an intermediate between $\mathrm{Na}_{2} \mathrm{FeO}_{4}$ and $\mathrm{Na}_{2} \mathrm{SO}_{4}$ formula $\mathrm{Na}_{2} \mathrm{Fe}_{\mathrm{x}} \mathrm{S}_{1-\mathrm{x}} \mathrm{O}_{4}$ and the most intense peak at $2 \theta=27^{\circ}$ (Figure 4), corresponds to the XRD spectrum of $\mathrm{Na}_{2} \mathrm{SO}_{4}$.

\section{Monitoring the Degradation of the Ferrate over Time}

Spectrophotometry is a quantitative analytical method of measuring the absorbance or optical density of a given chemical substance, generally in solution. The more concentrated the sample is, the more it absorbs light in the proportionality limits set by the Beer-Lambert law.

$$
\mathrm{A}=\mathrm{D} . \mathrm{O}=\log \left(\mathrm{I}_{0} / \mathrm{I}\right)=\varepsilon \mathrm{lC}
$$

The optical density of samples was determined by a spectrophotometer previously calibrated on the absorption wavelength of the test substance.

According to Sapin et al. [28], measuring the optical density of the solution of ferrate (VI) is at a wavelength of $507 \mathrm{~nm}$ with a $\mathrm{pH}$ greater than 10 .

The iron of the characteristic peak (VI) exits this wavelength.

The results of calculating the rate of degradation between the month and the state of the production ferrate VI and the different months of storage from the measured optical density is given by the following table.

The relation used to calculate the percentage of degradation of Iron (VI) is given by the following formula:

$$
\% \text { Degradation of the iron }(\mathrm{VI})=\left(\text { D. }_{\mathrm{i}}-\mathrm{D}_{\mathrm{O}} \mathrm{O}_{\mathrm{f}}\right) / \text { D.O }_{\mathrm{i}}
$$

D. $\mathrm{O}_{\mathrm{i}}$ : Optical densities of the iron (VI) respectively in the initial state;

D. $\mathrm{O}_{\mathrm{f}}$ : Optical densities of iron (VI) in the final state.

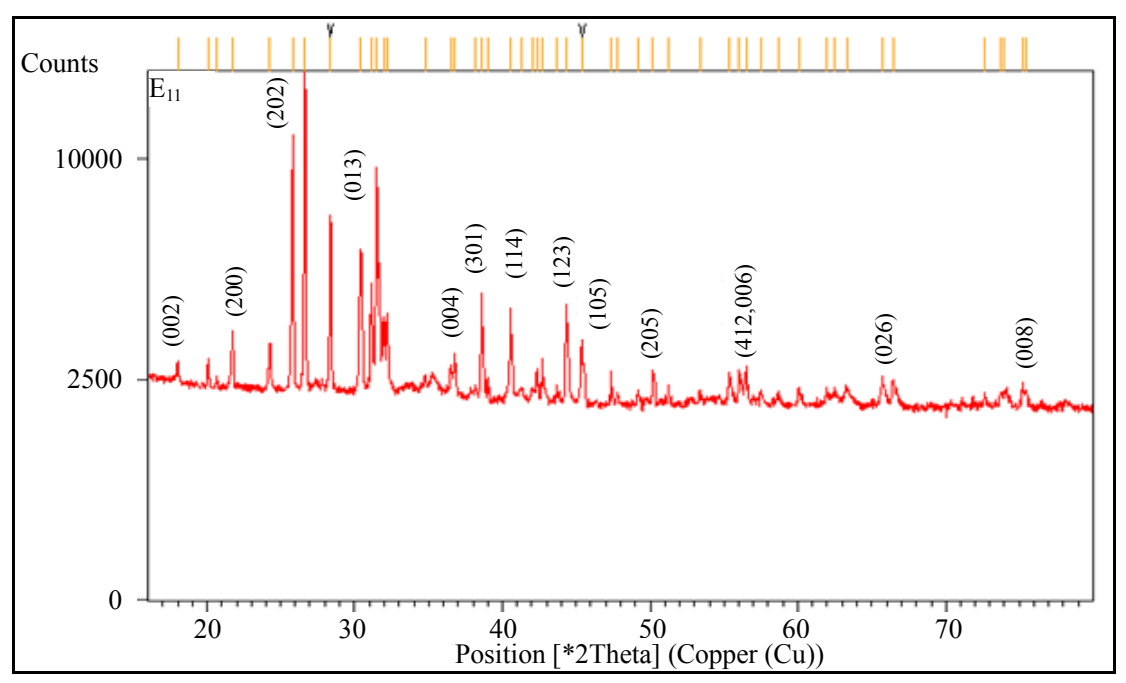

Figure 4. RX diffractogram prepared $\mathrm{Na}_{2} \mathrm{FeO}_{4}$. 
Table 1. Optical density of the solution of ferrate (VI) Phase $\mathrm{Na}_{2} \mathrm{FeO}_{4}$ synthesized according to the degradation rate between the initial state of the production and storage of ferrate VI during different months (\%) and based on the degradation rates between months storage of ferrate VI $(\%)$.

\begin{tabular}{ccc}
\hline $\mathrm{t}$ (months) & $\begin{array}{c}\text { The rate of deterioration from baseline in the production } \\
\text { and storage of different month ferrate VI (\%) }\end{array}$ & $\begin{array}{c}\text { The monthly rate of } \\
\text { degradation ferrate VI (\%) }\end{array}$ \\
\hline 1 & 0.7 & 0.7 \\
2 & 1.7 & 1.07 \\
3 & 3.57 & 1.81 \\
4 & 6.42 & 2.96 \\
5 & 7.5 & 1.14 \\
6 & 9.64 & 2.31 \\
7 & 29.28 & 2.17 \\
8 & 36.78 & 10.60 \\
9 & 38.21 & 2.25 \\
11 & 62.5 & 3.93 \\
\hline
\end{tabular}

According to our results (Table 1), the synthesized iron (VI) may be ambient stable during up to 12 months of storage at room temperature, and the iron degradation rate (VI) in the first six months does not exceed $9.64 \%$.

Note that the rate of degradation of iron (VI) remains variable in function of time and varies differently from one month to the other during storage. Climate change plays a very important role in the degradation rate of ferrate (VI) due to changes in humidity.

\section{Discussion}

The optimal degree of $\mathrm{ClO}^{-}$bleach or hypochlorite used for the synthesis of ambient stable $\mathrm{Na}_{2} \mathrm{FeO}_{4}$ is of the order of $50^{\circ} \mathrm{F}$. This rate plays an important role in iron (VI) synthesis yield.

This is comparable to the studies already made by Hrostowski and Scott [18] Thus, to obtain a strong and stable product requires a drying time of about 12 hours at a temperature of $120^{\circ} \mathrm{C}$ [12] [18].

According to the results, we found out that the duration of 12 months of storage is an important progress in the field of synthetic ambient stable iron (VI) to meet the growing global demand for it to get an industrial plant for the manufacture of this superoxydant and disinfectant [29].

\section{Conclusions}

This manuscript reviews the effect of the degree of bleach water ( $\mathrm{ClO}^{-}$hypochlorite) on the yield of the synthesis of iron (VI) and its stability over time. This level is of the order of $50^{\circ} \mathrm{F}$ with a drying time of 12 hours at a temperature of $120^{\circ} \mathrm{C}$.

Comparing stable $\mathrm{Na}_{2} \mathrm{FeO}_{4}$ synthesis results with the bibliography, we note that we have obtained for the first time wet ambient stable ferrates VI with quite a yield of $70 \%$ for a period of 12 months. This result represents a significant advance in the field of synthetic iron (VI) at a laboratory scale. This result is very encouraging for mass production of ferrate (VI) on an industrial scale.

\section{References}

[1] Hoy, G. and Corson, M. (1980) Critical Slowing Down of Spin Fluctuations in $\mathrm{K}_{2} \mathrm{FeO}_{4}$. Journal of Magnetism and Magnetic Materials, 15, 627.

[2] Menil, F. (1985) Systematic Trends of the ${ }^{57} \mathrm{Fe}$ Mössbauer Isomer Shifts in $\left(\mathrm{FeO}_{\mathrm{n}}\right)$ and $\left(\mathrm{FeF}_{\mathrm{n}}\right)$ Polyhedra. Evidence of a New Correlation between the Isomer Shift and the Inductive Effect of the Competing Bond T-X $(\rightarrow \mathrm{Fe})$ (Where X Is O 
or F and T Any Element with a Formal Positive Charge. Journal of Physics and Chemistry of Solids, 46, 763-789. http://dx.doi.org/10.1016/0022-3697(85)90001-0

[3] Licht, S., Naschitz, V., Halperin, L., Halperin, N., Lin, L., Chen, J., Ghosh, S. and Liu, B. (2001) Analysis of Ferrate(VI) Compounds and Super-Iron Fe(VI) Battery Cathodes: FTIR, ICP, Titrimetric, XRD, UV/VIS, and Electrochemical Characterization. Journal of Power Sources, 101, 167-176. http://dx.doi.org/10.1016/S0378-7753(01)00786-8

[4] Licht, S., Tel-Vered, R. and Halperin, L. (2002) Direct Electrochemical Preparation of Solid Fe(VI) Ferrate, and SuperIron Battery Compounds. Electrochemistry Communications, 4, 933-937. http://dx.doi.org/10.1016/S1388-2481(02)00493-9

[5] He, W.C., Wang, J.M., Shao, H.B., Zhang, J.Q. and Cao, C.-N. (2005) Novel KOH Electrolyte for One-Step Electrochemical Synthesis of High Purity Solid $\mathrm{K}_{2} \mathrm{FeO}_{4}$ : Comparison with $\mathrm{NaOH}$. Electrochemistry Communications, 7, $607-$ 611. http://dx.doi.org/10.1016/j.elecom.2005.04.011

[6] Xu, Z.H., Wang, J.M., Shao, H.B., Tang, Z. and Zhang, J.Q. (2007) Preliminary Investigation on the Physicochemical Properties of Calcium Ferrate(VI). Electrochemistry Communications, 9, 371-377. http://dx.doi.org/10.1016/j.elecom.2006.09.015

[7] Híveša, J., Benová, M., Bouzek, K., Sitek, J. and Sharma, V.K. (2008) The Cyclic Voltammetric Study of Ferrate(VI) Formation in a Molten Na/K Hydroxide Mixture. Electrochimica Acta, 54, $203-208$. http://dx.doi.org/10.1016/j.electacta.2008.08.009

[8] Wang, Y.L., Ye, S.H., Wang, Y.Y., Cao, J.S. and Wu, F. (2009) Structural and Electrochemical Properties of a $\mathrm{K}_{2} \mathrm{FeO}_{4}$ Cathode for Rechargeable Li Ion Batteries. Electrochimica Acta, 54, 4131-4135.

[9] Zuzana, M., Bouzek, K., Híveš, J., Sharma, V.K., Raymond, J.T. and Baum, J.C. (2009) Research Progress in the Electrochemical Synthesis of Ferrate(VI). Electrochimica Acta, 54, 2673-2683. http://dx.doi.org/10.1016/j.electacta.2008.11.034

[10] Jain, A., Sharma, V.K. and Mbuya, M.S. (2009) Removal of Arsenite by $\mathrm{Fe}(\mathrm{VI}), \mathrm{Fe}(\mathrm{VI}) / \mathrm{Fe}(\mathrm{III})$, and $\mathrm{Fe}(\mathrm{VI}) / \mathrm{Al}(\mathrm{III})$ Salts: Effect of pH and Anions. Journal of Hazardous Materials, 169, 339-344. http://dx.doi.org/10.1016/j.jhazmat.2009.03.101

[11] Lee, Y.H., Cho, M., Kim, J.Y. and Yoon, J.Y. (2004) Chemistry of Ferrate (Fe(VI)) in Aqueous Solution and Its Application as a Green Chemical. Journal of Industrial and Engineering Chemistry, 10, 161-171.

[12] Ockerman, L.T., Schreyer, J.M. and Thompson, G.W. (1951) Preparation and Purification of Potassuim Ferrate. VI. Journal of the American Chemical Society, 73, 1379-1381. http://dx.doi.org/10.1021/ja01147a536

[13] Schreyer J.M., Thompson, G.W. and Ockerman, L.T. (1953) Potasuim Ferrate (VI). Inorganic Synthesis, 4, $164-169$.

[14] Scholder, R., Bunsen, H., Kin, F., Zeiss, W. and Anorg, Z. (1955) Zur Kenntnis der Ferrate(VI). Zeitschrift für anorganische und allgemeine Chemie, 282, 268-279. http://dx.doi.org/10.1002/zaac.19552820129

[15] El Maghraoui, A., Zerouale, A. and Ijjaali, M. (2015) Process for the Synthesis of Ferrate(VI) Alkali Metal Dry. Advances in Materials Physics and Chemistry, 5, 10-15.

[16] Hrostowski, H.J. and Scott, A.B. (1950) The Magnetic Susceptibility of Potassium Ferrate. Journal of Chemical Physics, 18, 105-107. http://dx.doi.org/10.1063/1.1747423

[17] Hooker, A. (1920) Hipocloritos. Chem. and Met. eng., 23, 961.

[18] El Maghraoui, A., Zerouale, A., Ijjaali, M. and Sajieddine, M. (2013) Synthesis and Characterization of Ferrate(VI) Alkali Metal by Electrochemical Method. Advances in Materials Physics and Chemistry, 3, 83-87. http://dx.doi.org/10.4236/ampc.2013.31013

[19] Becarud, N. and Dural, C. (1963) Reactions and Properties of Potassium, Barium, and Strontium Ferrates. Comptes Rendus, 257, 1930-1933.

[20] Gonzales-Vilchez, F. and Griffith, W. (1972) Transition-Metal Tetra-oxo-Complexes and Their Vibrational Spectra. Journal of the Chemical Society, Dalton Transactions, 13, 1416-1421. http://dx.doi.org/10.1039/dt9720001416

[21] Griffith, W. (1966) Infrared Spectra of Tetrahedral Oxyanions of the Transition Metals. Journal of the Chemical Society A: Inorganic, Physical, Theoretical, 1467-1468. http://dx.doi.org/10.1039/j19660001467

[22] Tarte, P. and Nizet, G. (1964) Etude infrarouge de quelque composés du type $\mathrm{K}_{2} \mathrm{FeO}_{4}$ et $\mathrm{BaSO}_{4}$. Spectrochimica Acta, 20, 503-513. http://dx.doi.org/10.1016/0371-1951(64)80045-X

[23] Neveux, N. (1993) Voie de synthése originale de ferrates(VI) alcalins stabilisès et leurs applications potentielles dans le traitement des eaux. Thése de doctorat, Universitè de nancy I, Nancy.

[24] Krebs, V.H. (1950) The Structure of the Potassium Ferrate and Barium Ferrats with 2 Figures. Zeitschrift für anorganische und allgemeine Chemie, 263, 175-176. http://dx.doi.org/10.1002/zaac.19502630405

[25] Helfrich, B. and Lang, K. (1950) Uber salze der eisensaure. Zeitschrift für anorganische und allgemeine Chemie, 263, 
169-174.

[26] Audette, R.J. and Quail, J.W. (1972) Potassium, Rubidium, Césium, and Barium Ferrates VI: Préparations, Infrared Spectra, and Magnetic Susceptibilities. Inorganic Chemistry, 11, 1904-1908. http://dx.doi.org/10.1021/ic50114a034

[27] Lia, C., Lia, X.Z. and Grahamb, N. (2005) A Study of the Preparation and Reactivity of Potassium Ferrate. Chemosphere, 61, 537-543. http://dx.doi.org/10.1016/j.chemosphere.2005.02.027

[28] Tsapin, A.I., Goldfeld, M.G., Mcdonald, G.D., Nealson, K.H., Moskovitz, B., Solheid, P., Klemner, W., Kelly, S.D. and Orlandini, K.A. (2000) Iron(VI): Hypothetical Candidate for the Martian Oxidant. Icarus, 147, 68-78.

[29] El Maghraoui, A., Zerouale, A., Ijjaali, M. and Fikri Benbrahim, K. (2013) The Role of Ferrates(VI) as a Disinfectant: Quantitative and Qualitative Evaluation for the Inactivation of Pathogenic Bacteria. African Journal of Microbiology Research, 7, 3690-3697. 